...... Ugovšek, Budija, Kariž, Šernek: The Influence of Solvent Content in Liquefied Wood...

Aleš Ugov̌̌ek, Franc Budija, Mirko Kariž, Milan Šernek ${ }^{1}$

\title{
The Influence of Solvent Content in Liquefied Wood and of the Addition of Condensed Tannin on Bonding Qualify
}

\section{Utjecaj količine otapala u utekućenom drvu i dodatka kondenziranog tanina na kvalitetu vezanja}

\author{
Original scientific paper • Izvorni znanstveni rad \\ Received-prispjelo: 23. 11. 2010. \\ Accepted-prihvaćeno: 27. 4. 2011. \\ UDK: $630 * 824.31 ; 630 * 874.4$ \\ doi:10.5552/drind.2011.1039
}

\begin{abstract}
Liquefied wood $(L W)$ is a promising natural material that can be used as a part of the adhesive formulation. However, adhesive bonds made of LW only, have low durability. The aim of this study was, therefore, to increase the durability of adhesive bonds containing LW. LW was obtained with liquefaction of black poplar wood in ethylene glycol (EG) as the solvent and sulphuric acid (SA) as the catalyst. An optimal time of 120 minutes and a wood/EG mass ratio of 1:3 was defined for liquefaction at $180^{\circ} \mathrm{C}$. After liquefaction, the EG was evaporated in order to achieve a low solvent content $L W$ with a final mass ratio of 1:1. A hydroxyl number for 1:3 and 1:1 LW was determined in order to examine the reduction of hydroxyl groups. Four different adhesive mixtures were prepared: $L W$ with a mass ratio of $1: 1\left(L W_{1 \cdot 1}\right)$, $L W$ with a mass ratio of $1: 3\left(L W_{1 \cdot 3}\right), L W$ with a mass ratio of $1: 1$ and added condensed tannin $(C T)\left(L W_{1: 1} / C T\right)$, and $L W$ with a mass ratio of $1: 3$ and added $C T\left(L W_{1: 3} / C T\right)$. The solid beech wood lamellas, which were bonded with these adhesive mixtures, were tested directly after bonding, and later on, after 7, 30 and 50 days. The test results indicated greater bonding shear strength in the case of LW ${ }_{1: 1}$ compared to $L W_{1: 3}$. The addition of CT did not contribute to essentially higher shear strength values. The adhesive mixtures $L W_{1: 1}$ and $L W_{1: 1} / C T$ (uncured and cured) were analyzed using FT-IR spectroscopy. No significant differences were observed between the cured $L W_{1: 1}$ and the $L W_{1: 1} / C T$ samples.
\end{abstract}

Key words: adhesive, condensed tannin, FT-IR, liquefied wood, shear strength

SAŽETAK - Utekućeno drvo (LW) perspektivan je prirodni materijal koji može biti upotrijebljen kao tvar za izradu ljepila. Međutim, vezivna ljepila napravljena samo od utekućenog drva imaju malu trajnost. Stoga je cilj provedenih istraživanja bio povećati trajnost vezivnih ljepila koja sadržavaju LW. U provedenim je istraživanjima LW dobiven utekućenjem drva topole u etilen glikolu (EG) kao otapalu i sumpornoj kiselini (SA) kao katalizatoru. Definirano je optimalno vrijeme utekućenja od 120 minuta i maseni omjer drvo:EG u iznosu 1:3 za utekućenje pri temperaturi $180^{\circ} \mathrm{C}$. Nakon utekućenja EG je ishlapljen da bi se postigao nizak sadržaj otapala u LW-u s konačnim masenim omjerom 1:1. Utvrđen je hidroksilni broj za LW s omjerom 1:3 i LW s omjerom 1:1 da bi se ispitalo

\footnotetext{
${ }^{1}$ Authors are research assistant, researcher, assistant and associate professor at Biotechnical Faculty, University of Ljubljana, Ljubljana, Slovenia.

Autori su asistent istraživač, istraživač, asistent i izvanredni profesor na Biotehničkom fakultetu Sveučilišta u Ljubljani, Ljubljana, Slovenija.
} 
smanjenje broja hidroksilnih skupina. Pripremljene su četiri različite mješavine ljepila: LW s masenim omjerom 1:1 $\left(L W_{1: 1}\right)$, LW s masenim omjerom 1:3 $\left(L W_{1: 3}\right)$, LW s masenim omjerom 1:1 te dodanim kondenziranim taninom (CT) $\left(L W_{1: 1} / C T\right)$, i LW s masenim omjerom 1:3 i dodanim CT-om (LW $\left.W_{1: 3} / C T\right)$. Lamele od bukovine lijepljene su navedenim mješavinama ljepila i ispitane odmah nakon lijepljenja, zatim nakon 7, 30 i 50 dana. Rezultati testa pokazali su veću smicajnu čvrstoću vezanja u slučaju $L W_{1: 1}$ u odnosu prema $L W_{1: 3}$. Dodavanje CT-a nije znatno pridonijelo većoj smicajnoj čvrstoći. Mješavine ljepila $L W_{1: 1}$ i $L W_{1: 1} / C T$ (nesušene i osušene) analizirane su FT-IR spektroskopijom. Nisu zapažene signifikantne razlike između osušenih uzoraka $L W_{1: 1}$ i $L W_{1: 1} / C T$.

Ključne riječi: ljepilo, kondenzirani tanin, FT-IR, utekućeno drvo, smicajna čvrstoća

\section{INTRODUCTION}

1. UVOD

Adhesives are an indispensable part of wood-based composites. They are mainly composed of oil-based derivatives, which make them dependent on an ever-increasing oil price. One of the basic constituents of a large number of synthetic wood adhesives is formaldehyde, which is, however, potentially carcinogenic (IARC, 2004). Due to the free formaldehyde emission, the increasing prices of oil-based derivatives, strict environmental requirements, and increasing ecological awareness, there have been many attempts to produce wood adhesives based on natural and renewable sources.

Liquefied wood is one of the naturally-based products that has been developed in recent years. Liquefied wood is a product of the thermochemical reaction between wood (wood residues), solvent, and added catalyst. Liquefied wood can be used for the production of various biocopolymers. These biocopolymers include coatings (Budija et al., 2009; Kurimoto et al., 2000), various polymers (Wang et al., 2008; Doh et al., 2005), carbon fibres (Xiaojun and Guangjie, 2010), foams (Alma and Shiraishi, 1998; Lee and Ohkita, 2004), and adhesives.

Over the last 20 years there have been many attempts to use liquefied wood as a part of the adhesive formulation. In the earlier years, the development of liquefied wood adhesives was based on liquefied wood that was prepared with phenol and added formaldehyde (Alma and Bastürk, 2001, 2006; Li et al., 2004; Fu et al., 2006; Zhang et al., 2007). Many studies were performed in connection with the application of liquefied wood to epoxy resin systems (Kobayashi et al., 2000, 2001; Asano et al., 2007; Wu and Lee, 2010), and there have been some other attempts to blend liquefied wood with synthetic resins such as diisocyanates (Juhaida et al., 2010), urea-formaldehyde (Antonović et al., 2010), melamineurea-formaldehyde (Kunaver et al., 2010) and phenolformaldehyde resin (Ugovšek et al., 2010).

One of disadvantages of liquefied wood-based adhesives, besides low durability of the adhesive bond, is the low wood content in the final adhesive mixture. For example, if the wood/solvent mass ratio is $1: 3$, and later on $25 \%$ of the liquefied product is incorporated into the adhesive mixture, the latter will only contain $6.25 \%$ of wood (Ugovšek et al., 2010). Reducing the quantity of solvent in the final liquefied product was therefore the author's fundamental goal. This could either be achieved by liquefying at different wood/solvent mass ratios, or with solvent evaporation after liquefac- tion. Due to the higher content of the non-liquefied residue when liquefying at lower mass ratios (1:2 or 1:1), solvent evaporation turned out to be more appropriate method.

The above mentioned problem - low durability of liquefied wood based adhesives - could be potentially alleviated with the incorporation of a chemical substance that would help to crosslink the components of the liquefied wood. Based on the aim of creating an environmentally-friendly adhesive, the authors tried to use natural substances that are used as a part of adhesive mixtures. Tannins have been one of the most useful natural sources for wood adhesives (Gornik et al., 2000; Vázquez et al., 2002; Moubarik et al., 2009). They can be divided in two different classes, based on their chemical structure: hydrolyzable and condensed tannins. Almost all tannin-based wood adhesives are made from condensed tannins, due to their widespread availability and higher reactivity. The most reactive part of condensed tannin is resorcinol or the phloroglucinol A-ring of the flavonoid unit. The resorcinol A-rings of mimosa (Accacia sp.) and quebracho (Schninopsis sp.) tannins show reactivity toward formaldehyde that is comparable to that of resorcinol (Pizzi, 2008). In this study spruce condensed tannin was used, and it was found that it contained approximately $60 \%$ procyanidin and $40 \%$ prodelphinidin (Behrens et al., 2003). Condensed tannins can thus be added to liquefied wood due to their high reactivity at elevated temperatures, so that they can react with the free phenolic and alcoholic hydroxyl groups that are present in the liquefied wood.

The objective of this study was to optimize the liquefaction of black poplar (Populus nigra L.) using ethylene glycol (EG) as the solvent, and the preparation of liquefied wood with a low content of EG. Additionally, the properties of adhesive mixtures using liquefied wood with different solvent contents and added condensed tannin (hydroxyl number and infrared spectroscopy) were studied. Finally the shear strength of adhesive bonds that were produced with different adhesive mixtures was tested.

\section{MATERIALS AND METHODS} 2. MATERIJALI I METODE

\subsection{Preparation of liquefied wood} 2.1. Priprema utekućenog drva

Sawdust (fractions of $0.237 \mathrm{~mm}$ or smaller) of the black poplar (Populus nigra L.) was used for the production of liquefied wood. Prior to the liquefaction process, the sawdust was dried in a laboratory oven $\left(103{ }^{\circ} \mathrm{C}, 24\right.$ 
h). Ethylene glycol (p.a. grade) was used as the solvent, and sulphuric acid (p.a. grade) was used as a catalyst. $3 \%$ of SA based on the EG mass was added. Liquefaction was carried out in a $1000 \mathrm{~mL}$ three-neck glass reactor equipped with mechanical stirrer. The reactor was immersed in an oil bath that was preheated to $180^{\circ} \mathrm{C}$.

\subsection{Temporary amount of residue and liquefaction} yield determination

2.2. Određivanje količine ostatka i postignutog utekućenja

Different mass ratios between wood and EG (1:1, $1: 2,1: 3,1: 4,1: 5)$ and different liquefaction times were investigated in order to achieve the optimum results. By calculating the temporary amount of the residue (TAR), (Eq (1)) the optimum liquefaction time was assessed. During liquefaction, the samples of liquefied wood were dispossessed, diluted with a mixture of 1.4dioxane/water, and filtered through filter disks (Sartorius filter disks 388 grade $/ 84 / \mathrm{mm}^{2}$ ) every 15 minutes. The insoluble parts were dried in a laboratory oven $\left(103{ }^{\circ} \mathrm{C}, 24 \mathrm{~h}\right)$, and weighed in order to calculate the $T A R$ according to Eq (1).

$$
T A R=\left(1-\left(\frac{W_{1}-W_{2}}{W_{4}}\right)\right) \cdot 100 \%
$$

$W_{1}$ represents the mass of the filter paper with the dry residue $(\mathrm{g}), W_{2}$ is the mass of the filter paper $(\mathrm{g}), W_{3}$ is the mass of the dispossessed sample $(\mathrm{g})$, and TAR represents the temporary amount of the residue $(\%)$.

After the optimum liquefaction time, the reactor was immersed in cold water in order to quench the reaction. The liquefied product was then diluted with a mixture of 1.4-dioxane and water (4/1, v/v), and filtered through filter disks (Sartorius filter disks 388 gra$\mathrm{de} / 84 / \mathrm{mm}^{2}$ ) in order to remove the insoluble parts of the liquefied wood, with the aim of calculating the liquefaction yield $(L Y)$. The $L Y$ (i.e. the percentage of the 1.4-dioxane soluble part) was calculated for liquefied wood with wood/EG ratios of 1:2, 1:3 and 1:4, using Eq. (2). In order to obtain the liquefied wood containing EG, the mixture of 1.4-dioxane and water was evaporated at $55^{\circ} \mathrm{C}$ using a rotavapor instrument. Evaporation was performed under reduced pressure achieved by means of a vacuum pump.

$$
L Y=\left(1-\left(\frac{W_{1}-W_{2}}{W_{4}}\right)\right) \cdot 100 \%
$$

$W_{1}$ represents the mass of the filter paper with the dry residue $(\mathrm{g}), W_{2}$ is the mass of the filter paper $(\mathrm{g}), W_{4}$ is the mass of wood $(\mathrm{g})$ and $L Y$ represents the liquefaction yield $(\%)$.

After evaporation of the 1.4-dioxane, the EG in the LW was additionally evaporated $\left(120^{\circ} \mathrm{C}, 10 \mathrm{mbar}\right)$ to achieve a final mass ratio wood/EG of approximately $1: 1$. The mass of the evaporated EG was determined gravimetrically. The evaporation of the EG was also important due to very low viscosity of $\mathrm{LW}_{1: 3}$, which was problematic when applying LW to the wood surface prior to bonding.

\subsection{Determination of hydroxyl number of liquefied wood}

2.3. Određivanje hidroksilnog broja utekućenog drva

The hydroxyl $(\mathrm{OH})$ numbers of liquefied wood with wood/EG ratios of 1:3 $\left(\mathrm{LW}_{1: 3}\right)$ and 1:1 $\left(\mathrm{LW}_{1: 1}\right)$ were determined according to standard ASTM D 427405 , test method $\mathrm{C}$ - reflux phthalation. $0.45 \mathrm{~g}$ of sample $\mathrm{LW}_{1: 3}$ and $0.85 \mathrm{~g}$ of sample $\mathrm{LW}_{1: 1}$ was dissolved in 25 $\mathrm{mL}$ of a phthalic anhydride-pyridine reagent (115 g phthalic anhydride and $700 \mathrm{~mL}$ pyridine) and heated at $115 \pm 2{ }^{\circ} \mathrm{C}$, for $1 \mathrm{~h}$, under reflux. After esterification, 50 $\mathrm{mL}$ of pyridine was added through a condenser, and a phenolphthalein solution in pyridine was added. The mixture was titrated with $0.5 \mathrm{M}$ sodium hydroxide. Due to the dark colour of the solution and the severe difficulty in perceiving the colour change to pink, the titration end point was determined with a $\mathrm{pH}$ meter (Mettler Toledo, SevenEasy, pH meter S20). The end titration point was determined when a significant change in the $\mathrm{mV}$ value occurred.

\subsection{Preparation of adhesive mixtures \\ 2.4. Priprema mješavine ljepila}

The adhesive mixtures were prepared according to Table 1. Condensed tannin (CT) (Tanin Sevnica, Slovenia) from the Norway spruce (Picea abies L.) was used to prepare mixtures with different proportions of CT and LW.

\subsection{Bonding and testing of specimens \\ 2.5. Lijepljenje i testiranje uzoraka}

Solid beech wood lamellas were used as a substrate for the preparation of two-layered test specimens, which were bonded according to EN 12765 by using conventional hot-pressing. Prior to the bonding, all of the beech wood lamellas were planed in order to ensure

Table 1 Adhesive mixtures made of liquefied wood with different wood/solvent ratios and the addition of condensed tannin Tablica 1. Mješavine ljepila napravljene od utekućenog drva s različitim omjerom drva i otapala te s dodatkom kondenziranog tanina

\begin{tabular}{|l|c|c|c|}
\hline $\begin{array}{l}\text { Adhesive mixture } \\
\text { Mješavina ljepila }\end{array}$ & $\begin{array}{c}\text { Mass ratio between wood } \\
\text { and EG* } \\
\text { Maseni omjer drva } i \text { EG-a }\end{array}$ & $\begin{array}{c}\text { Weight portion of CT } \\
\text { Težinski udjel CT-a } \\
\%\end{array}$ & $\begin{array}{c}\text { Weight portion of LW } \\
\text { Težinski } u d j e l ~ L W-a \\
\%\end{array}$ \\
\hline $\mathrm{LW}_{1: 3}$ & $1: 3$ & 0 & 100 \\
\hline $\mathrm{LW}_{1: 3} / \mathrm{CT}(85 / 15)$ & $1: 3$ & 15 & 85 \\
\hline $\mathrm{LW}_{1: 1}$ & $1: 1$ & 0 & 100 \\
\hline $\mathrm{LW}_{1: 1} / \mathrm{CT}(85 / 15)$ & $1: 1$ & 15 & 85 \\
\hline
\end{tabular}

*EG - ethylene glycol / etilen glikol; CT - condensed tannin / kondenzirani tanin; LW - liquefied wood / utekućeno drvo 
smooth and flat surfaces. Two lamellas were then bonded together with different adhesive mixtures (Table 1). Each of the adhesive mixtures was applied by means of a roller, using an application rate of $200 \mathrm{~g} / \mathrm{m}^{2}$. The press temperature was $200{ }^{\circ} \mathrm{C}$, and the press time was 900 seconds. The specific press pressure was $1.5 \mathrm{MPa}$. The bonded specimens were tested immediately after bonding $(n=12)$, and later on after 7, 30 and 50 days of conditioning in a standard climate $\left(20 \pm 2{ }^{\circ} \mathrm{C}\right.$, relative humidity $65 \pm 5 \%$ ). All the shear tests were carried out on a ZWICK/Z005 universal testing machine according to the standard EN 205.

\subsection{FT-IR analysis}

\subsection{FT-IR analiza}

Fourier transform infrared spectroscopy (FT-IR) was used to investigate and compare the samples of $\mathrm{LW}_{1: 1}$ and $\mathrm{LW}_{1: 1} / \mathrm{CT}(85 / 15)$ in their uncured state. Both samples were later on placed on aluminium foil and cured in an oven for 600 seconds at $200{ }^{\circ} \mathrm{C}$. The cured $\mathrm{LW}_{1: 1}$ and $\mathrm{LW}_{1: 1} / \mathrm{CT}(85 / 15)$ specimens were also investigated using a Perkin-Elmer Instruments Spectrum One, FT-IR spectrometer. All the spectra were compared using Perkin-Elmer Spectrum 6.3.5 software. The spectra were recorded by the ATR technique, using a HATR ZeSn Trough Plate $45^{\circ}$, over the $4000-650 \mathrm{~cm}^{-1}$ wave number range. The spectral resolution of the spectrometer was $1 \mathrm{~cm}^{-1}$.

\section{RESULTS AND DISCUSSION}

3. REZULTATI I RASPRAVA

\subsection{Preparation of the liquefied product}

3.1. Priprema utekućenih proizvoda

The temporary amounts of residue versus the reaction time at different wood/EG ratios are shown in Figure 1. By calculating the TAR, the optimal liquefac- tion time was assessed. The optimum liquefaction time was assessed when the TAR was the least. The figure shows that the optimum liquefaction time for the ratios $1: 3,1: 4$ and $1: 5$ is above $120 \mathrm{~min}$. With the aim of achieving the lowest possible (and optimal) wood/EG ratio, the 1:3 ratio turned out to be optimal. In the case of the ratio 1:2 the lowest TAR was at 135 minutes. After 135 minutes the TAR increased and re-condensation of the liquefied product occurred. In the case of 1:1 ratio, wood liquefaction did not occur, and the stirring in the reactor was aggravated. The ratio 1:1 turned out to be inappropriate for wood liquefaction. The optimal time for liquefying black poplar wood at $180^{\circ} \mathrm{C}$ was therefore 120 minutes.

The LY was determined for LW with wood/EG mass ratios of 1:2, 1:3 and 1:4. The highest LY was attained at a mass ratio of 1:3 (91\%) and the lowest LY at a mass ratio of 1:2 (84\%). LY for LW with a mass ratio of $1: 4$ was similar to $\mathrm{LW}$ with a mass ratio of $1: 3$. Due to the above mentioned purpose of achieving the lowest wood/EG ratio, the LY for 1:5 ratio was not investigated. At 1:1 ratio, liquefaction did not occur. A wood/EG mass ratio of 1:3 was therefore the most appropriate for the liquefaction of black poplar with $\mathrm{EG}$, and 120 minutes at $180^{\circ} \mathrm{C}$ was required for the highest liquefaction yield.

The liquefaction process at the optimal conditions and the preparation of low-solvent liquefied product is shown in Figure 2. As can be seen, a theoretical wood/ EG mass ratio of 1:1 was obtained. The exact mass ratio of the final product was actually 1:1.05. The evaporation of EG also contributed to the suitable viscosity of the LW when applying it to the wood surface.

\subsection{Determination of hydroxyl number of liquefied wood \\ 3.2. Određivanje hidroksilnog broja za utekućeno drvo}

The $\mathrm{OH}$ numbers of the liquefied wood with different wood/EG mass ratios (1:3 and 1:1) was investi-

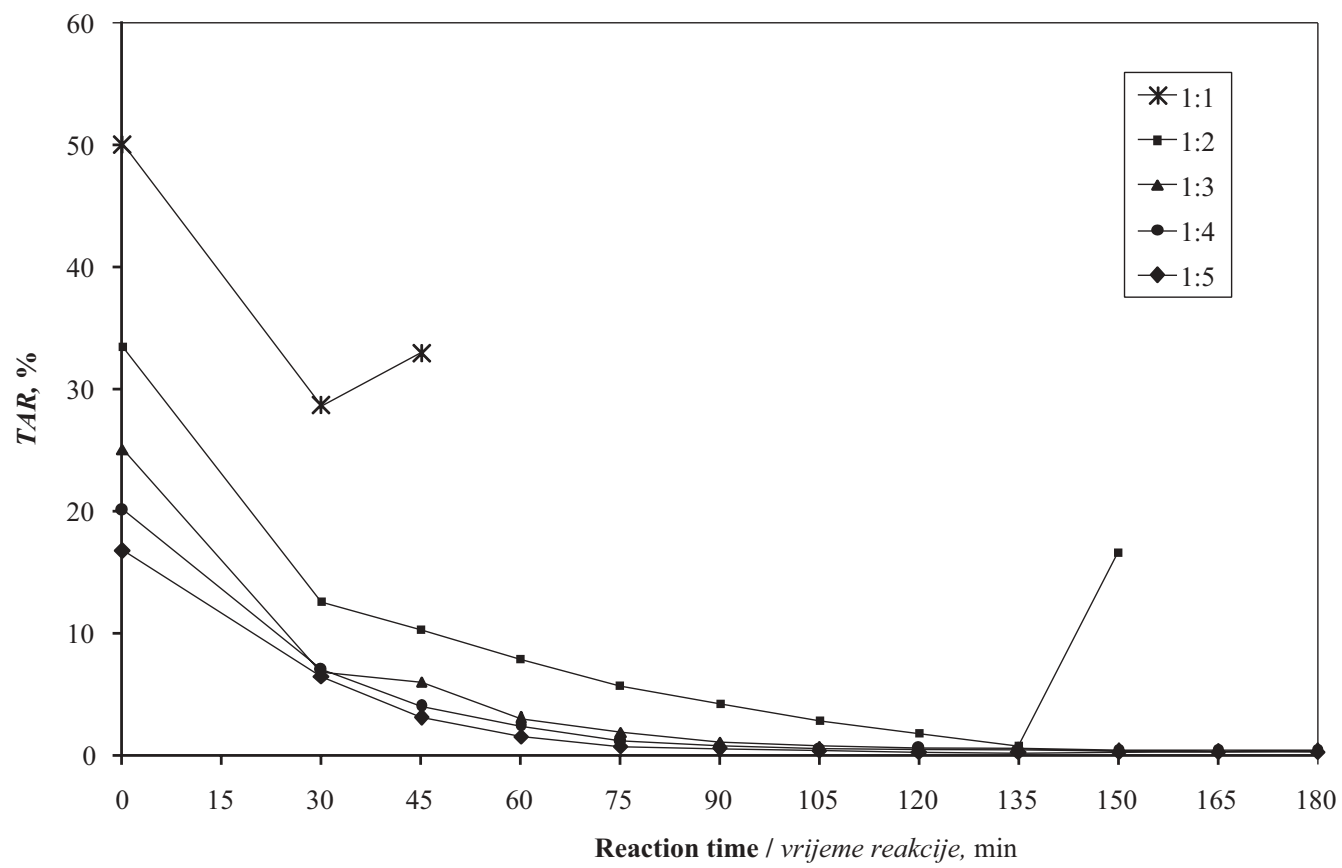

Figure 1 The temporary amount of residue $(T A R)$ at different liquefaction reaction times and different wood/EG ratios Slika 1. Privremena količina ostatka $(T A R)$ pri različitim vremenima reakcije utekućenja i različitim omjerima drva i otapala 


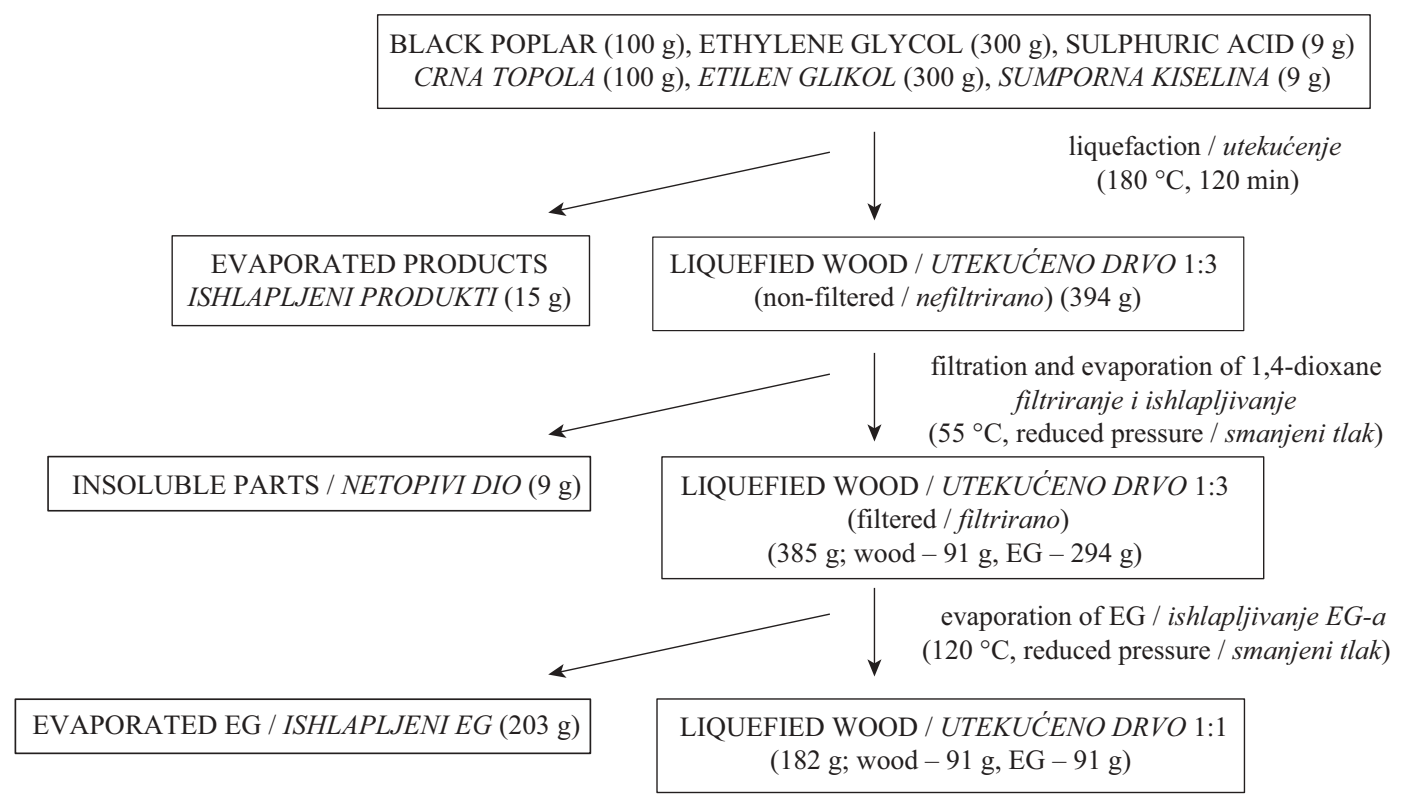

Figure 2 Liquefaction process and EG evaporation for achieving a final wood/EG mass ratio of 1:1

Slika 2. Proces utekućenja i ishlapljivanja EG-a za postizanje konačnog omjera drvo:EG u iznosu 1:1

gated as this could hypothetically affect the bonding properties of the specimens, and the durability of the bond-line. Table 2 shows the calculated $\mathrm{OH}$ number of the EG and determined $\mathrm{OH}$ number of the samples $\mathrm{LW}_{1: 3}$ and $\mathrm{LW}_{1: 1}$. Liquefaction of the wood significantly reduced the $\mathrm{OH}$ number of the liquefied product containing EG, which occurred due to the dehydration and thermal oxidation of the glycols, as well as due to the condensation reactions between the glycol and wood components, such as cellulose, hemicelluloses and lignin (Kunaver et al., 2010). The reduction of the $\mathrm{OH}$ number is also the consequence of solvent evaporation (Budija et al., 2009). It can be seen that the additional evaporation of EG to obtain a mass ratio of 1:1 lowered the number of $\mathrm{OH}$ groups to almost one half of the $\mathrm{LW}_{1: 3} \mathrm{OH}$ value. The reduction of free $\mathrm{OH}$ groups could potentially affect the durability of the bond-line. This is because free $\mathrm{OH}$ groups are potentially reactive locations, which interact with other functional groups, but are also possibly weak points for water deterioration if the adhesive bond is inadequately cured.

\subsection{Shear strength of tested specimens}

3.3. Smicajna čvrstoća ispitivanih uzoraka

The initial shear strength values of the specimens bonded with EG liquefied wood adhesive mixtures

Table 2 Hydroxyl numbers $(\mathrm{OH})$ of liquefied wood with wood/EG mass ratios of 1:3 and 1:1, and theoretically calculated hydroxyl number of $\mathrm{EG}$

Tablica 2. Hidroksilni broj $(\mathrm{OH})$ utekućenog drva s masenim omjerom drvo:EG u iznosu 1:3 i 1:1 te teorijski izračunana vrijednost hidroksilnog broja za EG

\begin{tabular}{|l|c|c|}
\hline $\begin{array}{l}\text { Substance } \\
\text { Tvari }\end{array}$ & $\begin{array}{c}\text { Wood/EG mass ratio } \\
\text { Maseni omjer drvo:EG }\end{array}$ & $\begin{array}{c}\text { OH (mg KOH/g) } \\
\text { Hidroksilni broj }\end{array}$ \\
\hline EG (theory) & $/$ & 1807 \\
\hline $\mathrm{LW}_{1: 3}$ & $1: 3$ & 1270 \\
\hline $\mathrm{LW}_{1: 1}$ & $1: 1$ & 667 \\
\hline
\end{tabular}

were low (Table 3), and also, they did not exceed the requirements of the standard for any of the durability classes. It is interesting that they did not decrease drastically over the following period of time, which is typically the main problem of bonding only with LW (Ugovšek et al., 2010). It can also be seen that the shear strength values of the adhesive mixtures with a wood/ EG ratio of 1:1 exhibited higher shear strength values than those with a ratio of $1: 3$. This was probably due to the more suitable viscosity of the sample $\mathrm{LW}_{1: 1}$, which contributed to the appropriate flow and penetration of the adhesive and wetting of the wood surface (Marra, 1992). The durability of the $\mathrm{LW}_{1: 1}$ adhesive bonds was also better compared to those corresponding to $\mathrm{LW}_{1: 3}$. The unreacted EG in the $\mathrm{LW}_{1: 3}$ influenced negatively the shear strength durability. The latter could be correlated to fewer free $\mathrm{OH}$ groups in the $\mathrm{LW}_{1: 1}$ than in the $\mathrm{LW}_{1: 3}$, which has more $\mathrm{OH}$ groups from the excessive EG. The free $\mathrm{OH}$ groups could be potential locations for water deterioration.

The addition of condensed tannin to the EG liquefied wood adhesive mixtures did not contribute significantly to higher shear strength values of the adhesive bond. This could be due to the high viscosity of the adhesive mixture containing tannin, and, consequently, poor penetration and anchoring. It could also be due to the low solubility of the tannins in the liquefied wood, which has a very low $\mathrm{pH}$ value (less than 1 ).

As the curing mechanism and the rate of crosslinking at the given curing conditions $\left(200{ }^{\circ} \mathrm{C}, 900 \mathrm{~s}\right)$ of the liquefied wood adhesive mixtures is not known, it should be investigated in the future.

The wood surface was considerably deteriorated in the area where the adhesive had been applied, which was probably the consequence of either liquefaction of the wood surface during pressing or acidic damage of the wood tissue due to very low $\mathrm{pH}$ of the adhesive mixture. The wood surface had, therefore, much lower shear strength values than normal (unaffected) wood, 
Table 3 Shear strength values $\left(\mathrm{N} / \mathrm{mm}^{2}\right)$ of specimens tested after conditioning in a standard climate for $0,7,30$ and 50 days, for adhesive mixtures containing wood liquefied with EG (1:3 and 1:1) or wood liquefied with EG with added condensed tannin

Tablica 3. Vrijednosti smicajne čvrstoće $\left(\mathrm{u} \mathrm{N} / \mathrm{mm}^{2}\right)$ ispitivanih uzoraka nakon kondicioniranja u standardnim uvjetima nakon 0, 7, 30 i 50 dana, za mješavine ljepila koje sadržavaju utekućeno drvo i EG (u omjeru 1:3 i 1:1) ili utekućeno drvo i EG uz dodatak kondenziranog tanina

\begin{tabular}{|c|c|c|c|c|c|c|c|c|}
\hline $\begin{array}{l}\text { Adhesive } \\
\text { mixture } \\
\text { Mješavina } \\
\text { ljepila } \\
\end{array}$ & \multicolumn{2}{|c|}{$\mathbf{L W}_{1: 3}$} & \multicolumn{2}{|c|}{$\mathbf{L W}_{1: 3} / \mathbf{C T}(\mathbf{8 5 / 1 5})$} & \multicolumn{2}{|c|}{$\mathbf{L W}_{1: 1}$} & \multicolumn{2}{|c|}{$\mathbf{L W}_{1: 1} / \mathbf{C T}(85 / 15)$} \\
\hline \multirow[t]{2}{*}{$\begin{array}{l}\text { Time, day } \\
\text { Vrijeme, } \\
\text { dani }\end{array}$} & \multicolumn{2}{|c|}{$\begin{array}{c}\text { Shear strength } \\
\text { Smicajna čvrstoća } \\
\mathrm{N} / \mathrm{mm}^{2}\end{array}$} & \multicolumn{2}{|c|}{$\begin{array}{c}\text { Shear strength } \\
\text { Smicajna čvrstoća } \\
\mathrm{N} / \mathrm{mm}^{2}\end{array}$} & \multicolumn{2}{|c|}{$\begin{array}{c}\text { Shear strength } \\
\text { Smicajna čvrstoća } \\
\mathrm{N} / \mathrm{mm}^{2}\end{array}$} & \multicolumn{2}{|c|}{$\begin{array}{c}\text { Shear strength } \\
\text { Smicajna čvrstoća } \\
\mathrm{N} / \mathrm{mm}^{2}\end{array}$} \\
\hline & Average & St.dev & Average & St.dev & Average & St.dev & Average & St.dev \\
\hline 0 & 5.4 & 0.95 & 4.7 & 1.08 & 5.8 & 1.06 & 5.8 & 1.01 \\
\hline 7 & 4.6 & 0.98 & 4.4 & 1.12 & 5.1 & 1.23 & 5.8 & 0.8 \\
\hline 30 & 5.2 & 0.96 & 4.5 & 1.02 & 4.8 & 0.66 & 5.2 & 0.64 \\
\hline 50 & 5.6 & 0.72 & 5.1 & 1.75 & 6.4 & 0.99 & 6.5 & 0.71 \\
\hline
\end{tabular}

and a higher percentage of wood failure (Figure 3). The latter is, apart from poor water resistance, the main problem that needs to be worked on.

\subsection{FT-IR analysis}

3.4. FT-IR analiza

Fourier transform infrared spectroscopy (FT-IR) was used to investigate and compare samples of $\mathrm{LW}_{1: 1}$ and $\mathrm{LW}_{1 \cdot 1} / \mathrm{CT}(85 / 15)$. Both samples were also cured (cured $\mathrm{LW}_{1: 1}$ and cured $\mathrm{LW}_{1: 1} / \mathrm{CT}(85 / 15)$ ) and their spectra were investigated. A comparison of all four spectra is shown in Figure 4. It can be seen that spectra corresponding to $\mathrm{LW}_{1: 1}$ and $\mathrm{LW}_{1: 1} / \mathrm{CT}(85 / 15)$ are almost indistinguishable, which is proof that there were no new functional groups in the $\mathrm{LW}_{1: 1} / \mathrm{CT}(85 / 15)$ adhesive mixture.

After curing, the spectra of the $\mathrm{LW}_{1: 1}$ and $\mathrm{LW}_{1: 1} /$ CT (85/15) mixtures changed. If the focus is placed on changes in peaks, then the most evident changes was at $1120 \mathrm{~cm}^{-1}$, which could correspond to the reduction of -OH groups after curing (evaporation and reaction of the solvent) (Budija et al., 2009) or C-O stretch in the cellulose (Pandey and Pitman, 2003). Reduction of the peak

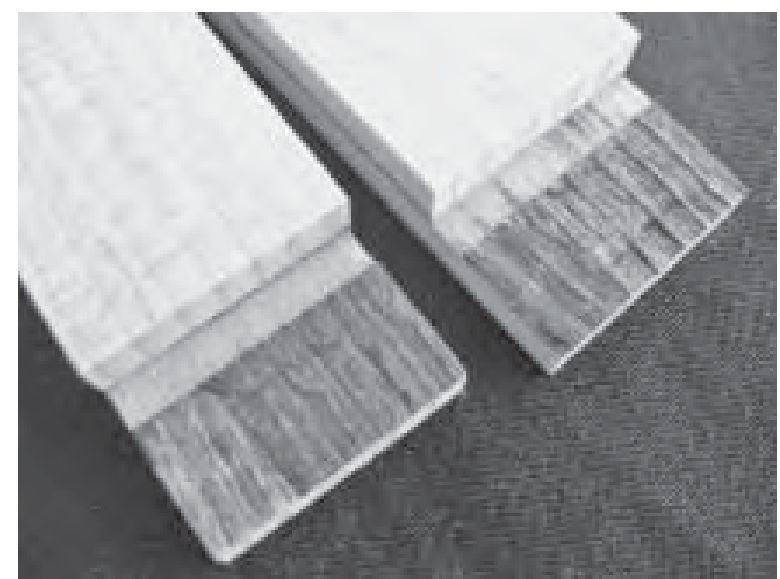

Figure 3 Wood failure and surface deterioration of the bonded specimens

Slika 3. Lom po drvu i uništenje površine slijepljenih uzoraka at $1050 \mathrm{~cm}^{-1}$ can be associated with $\mathrm{C}-\mathrm{O}$ stretch in the cellulose (glucose) (Morohoshi, 1991; Ibrahim et al., 2006; Gierlinger et al., 2008), and reduction in the peak at $883 \mathrm{~cm}^{-1}$ can be linked to antisymmetric out-of-phase stretching of cellulose (Morohoshi, 1991). All three peak reductions correspond to changes in the cellulose, or a reduction in the number of hydroxyl groups, which is a reasonable explanation and the consequence of curing. New peaks around $1090 \mathrm{~cm}^{-1}$ and $1020 \mathrm{~cm}^{-1}$ correspond to C-O ether vibrations (Budija et al., 2009). This indicates the presence of new compounds after curing.

A comparison of the spectra of the cured $\mathrm{LW}_{1: 1}$ and $\mathrm{LW}_{1: 1} / \mathrm{CT}(85 / 15)$ is shown in Figure 5. It explains the possible differences due to the addition of condensed tannin. Both spectra are rather similar, but with three differences in the fingerprint region. Reduction of the peak at $1242 \mathrm{~cm}^{-1}$ could either be associated with a syringyl ring and $\mathrm{C}-\mathrm{O}$ stretch in the lignin and xylan (Pandey and Pitman, 2003), or C-H and -OH deformation and C-O-C stretching vibration of the cellulose (Morohoshi, 1991; Gierlinger et al., 2008). The peak around $1065 \mathrm{~cm}^{-1}$ is attributed to pyranose ring stretching (Bouchard, 1990). The absorption at $853 \mathrm{~cm}^{-1}$ is associated with C-H outof-planes in positions 2, 5 and 6 of the $\mathrm{G}$ lignin units (vanillin) (Faix, 1991). It can be clearly seen that the latter absorption peak and the peak at $1242 \mathrm{~cm}^{-1}$ disappeared during the $\mathrm{LW}_{1: 1} / \mathrm{CT}(85 / 15)$ curing. This means that during the curing of the $\mathrm{LW}_{1: 1} / \mathrm{CT}(85 / 15)$ sample, vanillin and syringyl units of lignin, xylan or parts of cellulose could interact with the other functional groups or molecules. Despite the mentioned changes in the FTIR spectra of the cured $\mathrm{LW}_{1: 1}$ and $\mathrm{LW}_{1: 1} / \mathrm{CT}(85 / 15)$ samples, the effect of the addition of tannin to LW cannot be confirmed, which also coincides with the results of the shear strength test.

\section{CONCLUSIONS 4. ZAKLJUČCI}

The bonding properties of low solvent content liquefied wood, with the addition of condensed tannin, have been investigated. It was determined that the mass 


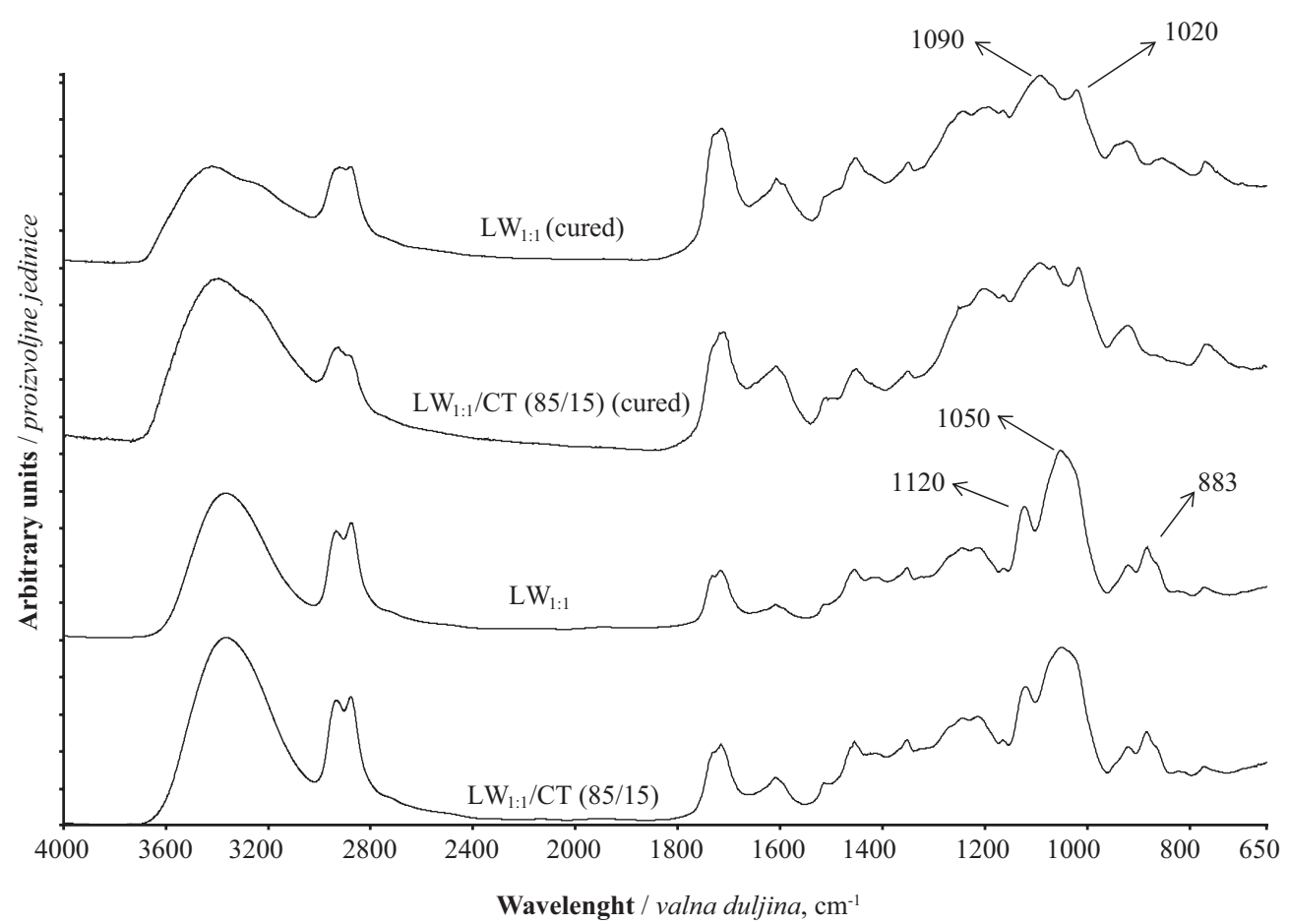

Figure 4 FT-IR spectra of liquefied wood with a wood/EG mass ratio of 1:1 $\left(\mathrm{LW}_{1.1}\right)$, liquefied wood with a wood/EG mass ratio of 1:1 and the addition of condensed tannin ( $\left.\mathrm{LW}_{1: 1} / \mathrm{CT}(85 / 15)\right)$, cured liquefied wood with a wood/EG mass ratio of 1:1 ( $\mathrm{LW}_{1: 1}$ (cured)), and liquefied wood with a wood/EG mass ratio of 1:1 and the addition of condensed tannin (LW $\mathrm{LW}_{1: 1} / \mathrm{CT}(85 / 15)$ (cured)) Slika 4. FT-IR spektar utekućenog drva s masenim omjerom drvo:EG u iznosu 1:1 ( $\left.\mathrm{LW}_{1: 1}\right)$, utekućenog drva s masenim omjerom drvo:EG u iznosu 1:1 i dodanim kondenziranim taninom ( $\left.\mathrm{LW}_{1: 1} / \mathrm{CT}(85 / 15)\right)$, utekućenog drva s masenim omjerom drvo: EG u iznosu 1:1 i osušen ( $\mathrm{LW}_{1 \cdot 1}$ (cured)), utekućenog drva s masenim omjerom drvo:EG u iznosu 1:1, dodanim kondenziranim taninom i osušen $\left(\mathrm{LW}_{1: 1} / \mathrm{CT}(85 / 15)\right.$ (cured))

ratio between the solvent and wood of 1:3 during liquefaction for 120 minutes at $180{ }^{\circ} \mathrm{C}$ was optimal in terms of the highest liquefaction yield achieved. The preparation of this low solvent liquefied wood was performed with ethylene glycol evaporation at $120^{\circ} \mathrm{C}$ and at redu- ced pressure. The final mass ratio obtained between the solvent and wood was 1:1. The hydroxyl group number of the low solvent $\mathrm{LW}_{1: 1}$ was reduced to almost one half of the $\mathrm{LW}_{1: 3}$ hydroxyl number after the evaporation of ethylene glycol. The specimens bonded with

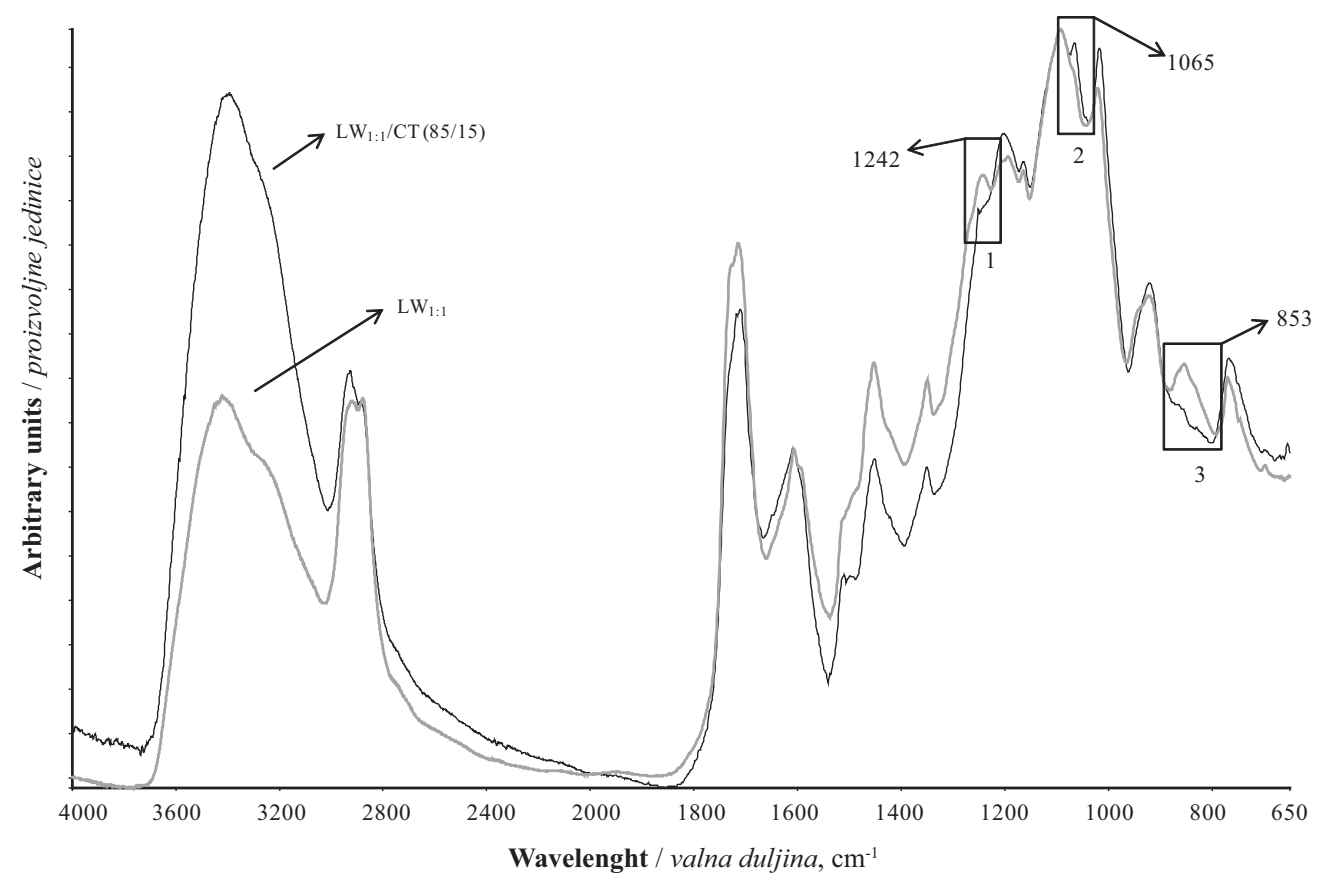

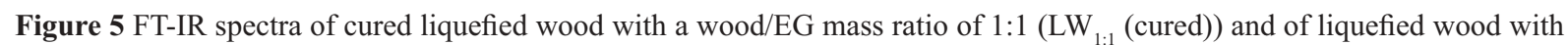
a wood/EG mass ratio of 1:1 and the addition of condensed tannin $\left(\mathrm{LW}_{1: 1} / \mathrm{CT}(85 / 15)\right.$ (cured))

Slika 5. FT-IR spektar osušenog utekućenog drva s masenim omjerom drvo:EG u iznosu 1:1 (LW LW $_{1.1}$ (cured)) i osušenoga utekućenog drva s masenim omjerom drvo:EG u iznosu 1:1 i dodanim kondenziranim taninom (LW $1: 1 / \mathrm{CT}(85 / 15)$ (cured)) 
liquefied wood $\left(\mathrm{LW}_{1: 1}\right.$ and $\left.\mathrm{LW}_{1: 3}\right)$, and the liquefied wood with added condensed tannin, were tested for shear strength. It was found that the evaporation of ethylene glycol contributed to better durability of the adhesive bonds. The addition of condensed tannin did not contribute essentially to better durability or higher shear strength. The specimens did not fulfil the requirements of the standard EN 12765 for any of durability classes. FT-IR spectra of the low solvent content LW, with and without the addition of condensed tannin, were investigated. Some minor differences among spectra were observed. The presence of new functional groups was not confirmed. The results of this study indicated that LW containing less EG (a mass ratio of 1:1) exhibited better bonding properties than LW with an initial mass ratio of $1: 3$, and that the addition of condensed tannin did not contribute to an improvement in the bonding quality.

\section{ACKNOWLEDGEMENTS - ZAHVALA}

The authors acknowledge the financial support of the Slovenian Research Agency through the Project J42177 and Research Program P4-0015.

\section{REFERENCES}

\section{LITERATURA}

1. Antonović, A.; Jambreković, B.; Kljak, J.; Španić, N.; Medved S., 2010: Influence of urea-formaldehyde resin modification with liquefied wood on particleboard properties. Drvna Industrija, 61(1):5-14

2. Alma, H. M.; Bastürk, M. A., 2006: Liquefaction of grapewine cane (Vitis vinisera L.) waste and its application to phenol-formaldehyde type adhesive. Industrial crops and products, 24: 171-176.

doi:10.1016/j.indcrop.2006.03.010

3. Alma, M. H.; Bastürk, M. A., 2001: Cocondensation of $\mathrm{NaOH}$-catalyzed liquefied wood wastes, phenol, and formaldehyde for the production of resol-type adhesives. Ind. Eng. Chem. Res., 40: 5036-5039. doi:10.1021/ie000858x

4. Alma, M. H.; Shiraishi, N., 1998: Preparation of polyurethane-like foams from $\mathrm{NaOH}$-catalyzed liquefied wood. Holz als Roh- und Werkstoff, 56: 245-246. doi:10.1007/s001070050311

5. Asano, T.; Kobayashi, M.; Tomita, B.; Kajiyama, M., 2007: Syntheses and properties of liquefied products of ozone treated wood/epoxy resins having high wood contents. Holzforschung, 61: 14-18. doi:10.1515/HF.2007.003

6. Behrens, A.; Maie, N.; Knicker, H.; Kögel-Knaber, I., 2003: MALDI-TOF mass spectrometry and PSD fragmentation as means for the analysis of condensed tannins in plant leaves and needles. Phytochemistry, 62: 11591170. doi:10.1016/S0031-9422(02)00660-X

7. Bouchard, J.; Garnier, G.; Vidal, P.; Chornet, E.; Overend, R. P., 1990: Characterization of depolymerized cellulosic residues .2. Residues derived from ethyleneglycol solvolysis cellulose. Wood science and technology, 24(2): 159-169.

8. Budija, F.; Tavzes, Č.; Zupančič-Kralj, L.; Petrič, M., 2009: Self-crosslinking and film formation ability of liquefied black poplar. Bioresource Technology, 100: 3316-3323. doi:10.1016/j.biortech.2009.02.004
9. Doh, G.; Lee, S.; Kang, I.; Kong, Y., 2005: Thermal behavior of liquefied wood polymer composites (LWPC). Composite structures, 68: 103-108. doi:10.1016/j.compstruct.2004.03.004

10. Faix, O., 1991: Classification of lignins from different botanical origins by FT-IR spectroscopy. Holzforschung, 45: 21-27. doi:10.1515/hfsg.1991.45.s1.21

11. Fu, S.; Ma, L.; Li, W.; Cheng, S., 2006: Liquefaction of bamboo, preparation of liquefied bamboo adhesives, and properties of the adhesives. Front. For. China, 2: 219224. doi:10.1007/s11461-006-0005-9

12. Gierlinger, N.; Goswami, L.; Schmidt, M.; Burgert, I.; Coutand, C.; Rogge, T.; Scwanninger, M., 2008: In situ FT-IR microscopic study on enzymatic treatment of poplar wood cross-sections. Biomacromolecules. 9: 21942201. doi:10.1021/bm800300b

13. Gornik, D.; Hemingway, R. W.; Tišler, V., 2000: Tanninbased cold-setting adhesives for face lamination of wood. Holz als Roh- und Werkstoff, 58: 23-30. doi: $10.1007 / \mathrm{s} 001070050380$

14. IARC (International Agency for research on cancer) 2004: IARC classifies formaldehyde as carcinogenic to humans. Press release $\mathrm{N}^{\circ} 153$. http://www.iarc.fr/en/media-centre/pr/2004/pr153.html (17.11.2010).

15. Ibrahim, M.; Alaam, M.; El-Haes, H.; Jalbout, A. F.; de Leon, A., 2006: Analysis of the structure and vibrational spectra of glucose and fructose. Eclética Química, 31(3): 15-21. http://www.scielo.br/pdf/eq/v31n3/02.pdf (17.11.2010).

16. Juhaida, M. F.; Paridah, M. T.; Mohd. Hilmi, M.; Sarani, Z.; Jalaluddin, H.; Mohamad Zaki, A. R., 2010: Liquefaction of kenaf (Hibiscus cannabinus L.) core for wood laminating adhesive. Bioresource technology, 101: 13551360. doi:10.1016/j.biortech.2009.09.048

17. Kobayashi, M.; Hatano, Y.; Tomita, B., 2001: Viscoelastic Properties of Liquefied Wood/Epoxy Resin and its Bond Strength. Holzforschung, 55: 667-671. doi:10.1515/HF.2001.108

18. Kobayashi, M.; Tukamoto, K.; Tomita, B., 2000: Application of liquefied wood to a new resin system-synthesis and properties of liquefied wood/epoxy resins. Holzforschung, 54: 93-97. doi:10.1515/HF.2000.014

19. Kunaver, M.; Medved, S.; Čuk, N.; Jasiukaityte, E.; Poljanšek, I.; Strnad, T., 2010: Application of liquefied wood as a new particle board adhesive system. Bioresource Technology, 101: 1361-1368. doi:10.1016/j.biortech.2009.09.066

20. Kurimoto, Y.; Takeda, M.; Koizumi, A.; Yamauchi, S.; Doi, S.; Tamura, Y., 2000: Mechanical properties of polyurethane films prepared from liquefied wood with polymeric MDI. Bioresource technology, 74: 151-157. doi:10.1016/S0960-8524(00)00009-2

21. Lee, S. H.; Ohkita, T., 2004: Ring-opening polymerization of cyclic esters onto liquefied biomass. Journal of polymers and the environment, 12(4): 203-210. doi:10.1007/s10924-004-8147-z

22. Li, G.; Qin, T.; Tohmura, S.; Ikeda, A., 2004: Preparation of phenol formaldehyde resin from phenolated wood. Journal of forestry research, 15(3): 211-214. doi:10.1007/BF02911027

23. Marra, A. A., 1992: Technology of wood bonding - Principles and practise. 1st ed. Van Nostrand Reinhold: New York.

24. Morohoshi, N., 1991: Chemical characterisation of wood and its components. Wood and cellulosic chemistry. Marcel Dekker, Inc., New York and Basel. 
25. Moubarik, A.; Pizzi, A.; Allal, A.; Charrier, F.; Charrier, B., 2009: Cornstarch and tannin in phenol-formaldehyde resins for plywood production. Industrial Crops and Products, 30: 188-193.

doi:10.1016/j.indcrop.2009.03.005

26. Pandey, K. K.; Pitman, A. J., 2003: FTIR studies of the changes in wood chemistry following decay by brownrot and white-rot fungi. International biodeterioration \& biodegradation, 52: 151-160.

doi:10.1016/S0964-8305(03)00052-0

27. Pizzi, A., 2008: Tannins: Major sources, properties and applications. In: Belgacem M. N., Gandini A. (Eds.) Monomers, polymers and composites from renewable resources. Elsevier, pp. 179-199. http://www.sciencedirect. com/science/book/9780080453163.

28. Ugovsek, A.; Kariz, M.; Sernek, M., 2010: Bonding of beech wood with an adhesive mixture made of liquefied wood and phenolic resin, in: Németh R. and Teischinger A. (Eds.). Proceedings of the "Hardwood Science and Technology" - The 4th conference on hardwood research and utilisation in Europe. Sopron, Hungary, 17-18 May 2010, 64-68.

29. Vázquez, G.; González-Álvarez, J.; López-Suevos, F.; Antorrena, G., 2002: Rheology of tannin-added phenol formaldehyde adhesives for plywood. Holz als Roh-und Werkstoff, 60: 88-91. doi:10.1007/s00107-001-0277-6

30. Wang, T.; Zhang, L.; Li, D.; Yin, J.; Wu, S.; Mao, Z., 2008: Mechanical properties of polyurethane foams prepared from liquefied corn stover with PAPI. Bioresource Technology, 99: 2265-2268. doi:10.1016/j.biortech.2007.05.003
31. Wu, C.; Lee, W., 2010: Curing behavior and adhesion properties of epoxy resin blended with polyhydric alcohol-liquefied Cryptomeria japonica wood. Wood Science and Technology, http://www.springerlink.com/ content/c35529h734w12m78/fulltext.pdf.

32. Xiaojun, M.; Guangjie, Z., 2010: Preparation of carbon fibers from liquefied wood. Wood science and technology, 44: 3-11. doi:10.1007/s00226-009-0264-3

33. Zhang, Q.; Zhao, G.; Yu, L.; Jie, S., 2007: Preparation of liquefied wood-based resins and their application in molding material. For. Stud. China, 9(1): 51-56. doi:10.1007/s11632-007-0009-Z

34. ${ }^{* * *}$ EN 205: 2003: Adhesives - Wood adhesives for nonstructural applications - Determination of tensile shear strength of lap joints: $13 \mathrm{pp}$.

35. *** EN 12765: 2002: Classification of thermosetting wood adhesives for non-structural applications: 9pp.

\section{Corresponding address:}

Assoc. Prof. MILAN ŠERNEK, Ph.D.

University of Ljubljana, Biotechnical Faculty Department of Wood Science and Technology Rožna dolina, C. VIII/34

SI-1000 Ljubljana, SLOVENIA

e-mail: milan.sernek@bf.uni-lj.si 